Филолошки факултет - докторске студије, модул Култура

Београд

Електро-техничка школа у Смедереву

Техничка школа Смедерево

olivera.petrovic1988@gmail.com

\title{
УЛОГА МЕНТОРА РОМА У СРЕДЬОЈ ШКОЛИ
}

\begin{abstract}
АПСТРАКТ
У овом раду представља се улога ментора за ученике ромске националности који похађају средње школе, из перспективе социолингвистике, односно интеркултурности. Опис посла ментора биће расветљен кроз идеје образовне језичке политике, однос према ромском језику и интеракцију истог са већинским језиком, те идеје плурилингвизма. Потом ће бити предочен успешан програм менторства у Србији кроз представљање ТАРИ пројекта, те резултате истраживања у којем су учествовалиментори из централне Србије. Полазећи од претпоставке да ментор има важну улогу у формирању позитивних ставова према аутентичном наслеђу, специфичностима ромског језика и културе, као и према мотивацији за континуирано образовање, у раду се залажем за став да сваки ментор може утицати на подизање нивоа етничке самосвести и престижа ромске мањине, што би даље могло доприносити унапређењу ромске заједнице а тиме и шире националне, односно наднационалне заједнице.
\end{abstract}

Кључне речи: Роми, ментор, менторство, образовна језичка политика и планирање, плурилингвизам, интеркултурна компетенција, ТАРИ пројекат, цена ексклузије

\section{THE ROLE OF A MENTOR TO ROMA SECONDARY-SCHOOL STUDENTS}

ABSTRACT 
This paper discusses the role of a mentor for Roma students attending secondary schools, from the perspective of sociolinguistics, and interculturalism. Job description of a mentor will be shown through the idea of educational language policy, the attitude towards the Roma language and its interaction with the language of majority and the idea of multilingualism. The paper also presents the successful mentoring program in Serbia through the presentation of TARI project, and the results of the research in which mentors from central Serbia participated. Assuming that a mentor has an important role in the formation of positive attitudes towards the authentic heritage, the specifics of the Roma language and culture, as well as the motivation for continuing education, the author advocates the view that each mentor can influence the raise of the level of ethnic self-awareness and prestige of the Roma minority. It could consequently contribute to the improvement of the Roma community and thus the broader national or international community.

Key words: Roma students, mentor, mentorship, language education policy and planning, plurilingualism, intercultural competence, the TARI project, the price of exclusion

\section{1. УВОД}

У овом раду расветљава се улога ментора за ученике ромске националности који похађају средње школе, из перспективе социолингвистике, односно интеркултурности, узимајући у обзир да је социолингвистика динамичка, интердисциплинарна, критичка хуманистичка наука, која се бави односом језика и друштва. Премда се нећемо задржавати на пукој дефиницији ментора и менторства, опис посла ментора биће понуђен кроз идеје образовне језичке политике, однос према ромском језику и интеракцију истог са већинским језиком, те идеје плурилингвизма. Сматрам да би ментор могао да има пресудну улогу у процесу формирања ставова, мишљења и мотивације за континуирано образовање и напредовање, а које би даље утицало на побољшање стања на тржишту рада. Премда у Србији није реткост да дела не прате политику образовних институција, залажем се за став да би сваки ментор могао малим корацима унети промене које би кумулативним радом на територији читаве државе водиле великом помаку ка сузбијању дискриминације, сегрегације и угрожавања људских права. Пример добре праксе менторства у Републици Србији нуди нам приказ пројекта „Овде смо заједно“, те резултата истраживања, које потом прате закључна разматрања. 


\section{2. ДЕФИНИЦИЈА И ОПИС ПОСЛА МЕНТОРА}

Парсло (1992) дефинише улогу ментора - он или она пружа помоћ и подржава особу у управљању сопстеним учењем, повећава његов или њен потенцијал, развија вештине, побољшава успешност и помаже ученику да постане човек какав та особа жели да буде. Премда су дефиниције менторства бројне (Parsloe, 1992; Rolfe, 2006), све подразумевају савез два појединца у чијем процесу обе стране уче и напредују, а који не подразумева хијерархијски однос надређеног и подређеног, већ почива на међусобом поверењу, уважавању и спремности обе стране да се развијају лично и професионално. Речју, менторство негује индивидуални приступ ученику. Такође, развијање самопоуздања и мотивације кључно је за постизање добрих резултата, а Жиропађа (2012) истиче разлику између интринзичне и екстринзичне мотивације. Узимајући у обзир да долазе из социјално маргинализованих група, ученицима ромске националности потребна је додатна мотивациона подршка приликом школовања коју сваки ментор може неговати.

Опис посла ментора могао би се поделити у категорије, које нису искључиве и које би, напротив, требало да се допуњују - рад са ученицима, комуникација са родитељима, интеракција са школом и предметним наставницима, као и сарадња са локалном заједницом. Ни за једну од поменутих категорија не може се рећи да је важнија или да има предност. Премда би много могло да се каже о свим пољима делања једног ментора, задржаћу се на социолингвистичкој и интеркултурној димензији.

Расизам, сеграгација и дискриминација у школама према ученицима ромске националности уочљиви су на свим нивоима образовања.Према попису из 2011. године Роми у Србији сачињавају 2.05\% укупног становништва, односно око сто четрдесет осам хиљада ${ }^{1}$. Републички завод за статистику уз техничку и финансијску подршку UNICEF-а изнедрио је Извештај заснован на Истраживању вишеструких показатеља положаја жена и деце у Србији у 2014. години, односно у ромским насељима у Србијиㄹ. Занимљиво је да према извештају ОСЦЕ-а за Србију не постоји податак колико је Рома уписано у средње школе. Ипак, у поменутом Извештају указује на то да

1 Детаљни и класификовани подаци најновијег пописа у Републици Србији доступни су на званичном сајту Републичког завода за статистику www.popis2011.stat.rs.

2 Истраживање вишеструких показатеља стања и положаја жена и деце у Србији 2014, односно истих у ромским насељима доступно је у пдф формату на интернет страници www. unicef.org/serbia/MICS5_Srpski_web.pdf. 
око девет процената заврши средњу школу. ${ }^{3}$ Процентуално посматрано, 22\% деце средњошколског узраста (14-18 година) похађа средњу школу, $14 \%$ њих је и даље у основној, док забрињавајућих 64\% уопште не иде у школу (МИЦС \& УНИЦЕФ, 2014). Такође, уочљиве су разлике у похађању средње школе између дечака и девојчица - дечака има $28 \%$, док је проценат девојчица знатно мањи и износи 15\%. Занимљиво је да је индекс једнакости полова код већинског становништва за средњу школу 1,08, док исти за Роме пада на 0,53. Стопа завршавања основне школе је 93\% у већинском, односно 64\% код Рома, а стопа преласка у средњу школу износи 96\%, односно свега 59\% за припаднике ромске националности.Овакви подаци јесу забрињавајући али уз адекватну подршку могуће их је преокренути. У наставку ће бити речи о образовној језичкој политици и улози ментора у спровођењу исте, те о односу према језику и плурилингвизму.

\section{3. ЈЕЗИЧКА ПОЛИТИКА И ПЛАНИРАҢЕ И ОБРАЗОВНА ЈЕЗИЧКА ПОЛИТИКА И ПЛАНИРАЬЕ}

Сложила бих се да је потребно формирати такву образовну политику која „ће инсистирати на једнакости, плурикултурности, толеранцији и уважавању различитости. То се може постићи адекватном обуком наставног особља у области мултикултурног образовања и законским актима којима се ван закона ставља и значајно санкционише дискриминација у области образовања“" (Филиповић, 2009а: 84). Филиповић и Вучо (2012) аргументовано приказују нови приступ језичкој политици и планирању, кроз лидерство у језику, у којем се друштвено устројство поима хетерархијски.

Не смемо пренебрегнути да су исходи језичке политике и планирања (ЈПП) увек у корелацији са социополитичким, епистемолошким и стратешким ставовима оних који о истој одлучују. У такозваној трећој фази ЈПП-а развија се концепт језичких људских права. Снажно подржавам Бугарсков (2005) интерактивни модел језичке политике који постулира културну и лингвистичку интеракцију различитих језика, међусобну сарадњу и разумевање говорника, уз препознавање културне, етничке, као и расне специфичности. Образовна језичка политика и планирање (ОЈПП), као саставни део језичке политике, такође осликава ставове својих твораца.

3 Интернационални компаративни подаци за Роме у примарном, секундарном и терцијарном образовању за Средњу, Источну и Североисточну Европу доступни су на сајту www.opensocietyfoundations.org. 
Иако закон предвиђа могућност организовања двојезичне наставе, ромски језик према досадашњим сазнањима није заступљен у средњим школама у Србији. Такође, један од проблема ОЈППА-а у Србији јесте да мањински језици нису предвиђени за неприпаднике регионалних заједница, што не доприноси развоју интеркултурне компетенције, толеранције и интеретничке комуникације, те се истовремено неоправдано повећава јаз између већинског и мањинског становништва. С друге стране, школовање на Л1 мањина води често суптрактивном билингвизму и немогућности даљег академског, професионалног и друшвеног напредовања (Филиповић, Вучо и Ђурић, 2007). Нажалост, у земљи и даље предњачи националистички модел, иако „(у)чење других језика унапређује опште когнитивне и метакогнитивне вештине, унапређује познавање сопственог Л1, као и вештину читања и писања и развија опште комуникативне вештине“ (Филиповић 2009а: 71). У Србији још увек нису јасно утврђене методе и план и програм наставе ромског језика, као уосталом и регионалних језика, које би подстакле виши ниво комуникативне компетенције, односно развој прагматичких и социолингвичких аспеката у језику, поред способности читања и писања (ибид.).

Филиповић (2009) расветљава проблем образовања ромске популације и доводи га у везу са етницитетом, језиком и вековима ускраћиваној друштвеном моћи. Једино је у Војводини систематично спроведено истраживање о односу етницитета и Л1 говорника (Филиповић, Вучо и Ђурић, 2007 према Mikes, 2001), где се показало да 98.4 процента становништва изједначава свој етницитет са језиком.Избор језика у образовању одређује и ко има приступ образовању. Треба напоменути да су на крају 2014/2015. школске године разредне старешине у средњим школама имале задатак да поделе анкете које су попуњавали родитељи ученика који припадају националним мањинама а који су се изјашњавали на ком језуку би желели да њихова деца слушају наставу, на пример ромском, мађарском, итд. Међутим, нама до данас нису доступни могући резултати поменуте анкете.

Када је реч о неуспеху, он се често приписује представницима мањинских заједница, са чиме је повезана такозвана теорија дефицита, према којој се основни проблем ромске заједнице огледа у наводном ниском нивоу општих когнитивних способности, а из које су проистекли непрограми интеграције. У Србији су дуго били на снази програми тоталне имерзије, према којима су Роми уписивани у једнојезична српска одељења првог разреда основне школе без икаквих припрема (Филиповић 2009б). Не треба заборавити да су Роми тек 2003. године стекли статус националне мањине у Републици Србији. Да сумирамо, нејасно дефинисан приступ образовању и 
настави има за последицу недовољно напредовање како у српском, тако и у ромском језику.

У сфери образовања, Роми су у Србији, али и у Европи, најугроженија национална мањина. Једном кад приступе образовању, проблем језика образовања постаје кључни. Ромски језик је специфичан, јер не постоји језички код који би олакшавао описмењавање на језику примарне социјализације. Стога, како тврди Филиповић (2009а), издвајају се две струје; на једној страни се ромска образовна елита залаже за формирање јединственог, интернационално признатог језичког кода, што одговара националистичком моделу језичке стандардизације, док са друге стране емпиријска искуства указују да је такав приступ нереалан, јер премда се расправља о ромском писму, приступ образовању на ромском језику не постоји. Сложила бих се да такозвани bottom-up процеси треба да буду подржани од стране top-down језичке политике, односно сама етнојезичка заједница мора да инсистира на комуникативној вредности сопственог варијетета. Сложила бих се са Филиповић (2009: 13) да „није потребно да одређени систем има богату писану књижевност (или писмо уопште) како би се третирао као пуноправан језички систем“. Дакле, иако за ромски језик не постоји формално писмо, то не би требало да имплицира подређеност, што би даље подразумевало разговор ментора са ученицима, али и родитељима о поменутом. Најпре, неопходно је да сами ментори заузму активан став о значају плурилингвизма и поседовању компетенција у већем броју језика, а потом исте пренесу на своје ученике, као и на ширу јавност.

Уколико желе образовно или професионално да иступе из ромске мањинске средине, јасно је да Роми морају да савладају најпре већински језик. Премда је према Филиповић (2009a) етнички, мањински, језик самоједан од елемената формирања и чувања етницитета, односно етничког идентитета које појединац или група користе у различитим контекстима, са чиме бих се сложила, ментори би требало да користе сваку прилику како би пренели позитиван став према улози ромског језика, његовим функцијама и вредностима у очувању етницитета и етничког идентитета. Бројни друштвено-културни фактори, као и социјални и културни притисак којем су изложени, утичу на Роме да нагињу већинском језику, што често доводи до диглостичне комуникативне ситуације. „Представници мањинских заједница (се) у највећем броју случајева не интегришу, већ асимилују у већинску заједницу, при чему замена језика утиче на брзину асимилације“ (Филиповић 2009а:102). Отворено је питање да ли асимилација подразумева и губитак етничког идентитета. Да закључимо, потребно је редефинисање става према мањинском ромском језику, а да би то било омогућено ментори 
би требало да инсистирајуна развијању концепта друштвене инклузије и индивидуалног плурилингвизма.

Филиповић, Вучо и Ђурић (2007) наводе као основну хипотезу да је плурилинвизам у образовању идеалистички концепт докле год се питања политичке и друштвено-економске моћи језика не узму озбиљно у разматрање, односно да се ЈПП не може никада изоловати од одређеног друштвено-политичког, научног и културног контекста.,Плурилингвизам је способност појединаца да током читавог живота у свакодневној говорној пракси користи различите језике које познаје на различитим нивоима комуникативне компетенције. Циљ европских институција је Европа плурилингвалних појединаца (...)“ (Филиповић 2009: 61). У погледу менторства, задатак ментора био би да код ученика подржава проактивни став према ромском језику и очувању језичке разноликости.Циљ је да се сваки појединац служи језицима за које он сматра да су му потребни и да играју улогу у комуникацији, изградњи његовог/њеног идентитета, и личном и професионлном развоју и образовању. „Уколико се овом циљу не посвети довољна пажња, уколико се он не експлицира на нивоу образовних политика релевантних државних институција, мултилингвизам ће остати привилегија само високообразоване елите у европским државама“ (Филиповић 2009a: 71).

Онионс (2010) анализира и поткрепљује став Европског суда за људска права да су такозвана специјална одељења, у која често доспевају деца ромске националности у судару са едукацијом која се базира на недискриминацији и интегрисаности, као и са Конвенцијом о заштити људских права и основних слобода. Посебан акценат треба ставити на ромску децу у реадмисији, као и на интерно расељењу. Филиповић(2009б) се залаже и препоручује инклузивни модел језичке и образовне подршке у којем циљну популацију чине ромска деца интерно расељених лица, пристигла првенствено са територије Косова и Метохије, као и лица у реадмисији, која према незваничним подацима долазе углавном са немачког говорног подручја. Оваква деца „морају имати право на унапређење компетенција у српском као језику образовања“ (...) (Филиповић, 2009б). Такође је истакнуто да језичку подршку треба да прати образовна подршка. Премда не постоји званични податак колико ромске деце из горе-поменутих група упише средњу школу, из досадашњег професионалног искуства Роми који досегну секундарни ниво образовања поседују одређене компетенције на српском језику као Л2, те би због тога сваки ментор требало да ставља акценат на образовну подршку поред језичке. Према Филиповић (2009б) ромским ученицима треба помоћи да усвоје културне обрасце познате њиховим 
вршњацима, развију стратегије учења, као и аутономију. Штавише, сматрам да се рад ментора може надовезати на рад посебно едукованих наставника/ професора у предшколским установама и основним школама који спроводе језичку подршку са циљем обезбеђивања услова за стицање компетенција у српском језику.

Када је реч о образовању, не смемо изоставити курикуларну праксу у Србији. Филиповић (2009а) указује на Извештај високог комесара Макс ван Стоела ОЕБС-а о ситуацији у којој се налазе Роми и Синти у ОЕБС региону из 2000. године, који указује на екслузију ромских културних садржаја у оквиру редовног курикулума. Наравно, иако би то подразумевало одступање од прописаног градива, сваки ментор-наставник могао би у оквиру сопственог предмета уврстити садржаје који би утицали на повећање интеркултурне компетенције. Премда Филиповић (2009а) не помиње менторство, она наводи опште трендове развоја бројних пилот пројеката, који би дакако били наглашенији уколико би им се и ментори посветили у свом раду. На пример, неке од запажених тенденција јесу пружање подршке мултикултурном образовању, увођење обука, као и повећан број ромских асистетана, наставника и медијатора. Такође, сваки ментор-наставник може увести у своју наставну, односно курикуларну праксу развој ромске историје и културе те тиме стварати основу за развој интеркултурне компетенције и прихватање различитости. Такође, у средњој школи сваки ментор би требало да упознаје своје ученике са екстракурикуларним програмима подршке и упућује на развој самоиницијативних пројеката.

\section{4. ПОВЕЗАНОСТ МЕНТОРСТВА РОМА И ТРЖИШТА РАДА}

Истакнуто је да очување мањинских језика и култура, уз развијање интеркултурне компетенције и толеранције, може смањити друштвене конфликте, односно да поред моралних и етичких постоје оправдани економски фактори који подржавају политику језичких права. Узимајући у обзир да се само један проценат Рома уписује на факултете, „недовољно образовани и неприпремљени Роми нису у стању да се такмиче на све захтевнијем тржишту рада““ (Филиповић, 2009а: 82).

Премда тема овог рада нису статистички економски и фискални подаци, проналазим да је важно поменути поједине, који се тичу образовања Рома, а тиме посредно утичу и на схватање важности менторства. ДеЛаат (2010) наводи економску цену ексклузије Рома, као и чињеницу да премошћивање несклада у образовању представља и економски мудар 
избор. Такође наводи да Роми који заврше средњу школу могу да очекују зараду већу за 52\% у Србији. Једнако учешће Рома у раду помогло би да се изађе на крај са трошковима који расту зато што већинско становништво у Источној и Централној Европи нагло стари. Закључује се да би фискални добици од превазилажеља несклада у запошљавању били већи од трошкова улагања у образовање ромске деце. Према наводима Светске банке Роми спадају међу најсиромашније заједнице у Европи, пошто су често искључени са тржишта рада. ${ }^{4}$

Ниска образовна достигнућа огледају се у ниским стопама запослености - у Србији тек 1 од 8 радно способних Рома има средњошколско образовање или виши степен образовања, односно свега 1 од 5 радно способних Рома има запослење. Последично, зараде Рома много су ниже у односу на исте код већинског становништва. ДеЛаат (2010) наводи, а ми бисмо се сложили, да комбинација ниског нивоа запошљавања и ниских плата имплицира неумитно губитке у продуктивности у целокупној привреди. Освртом на раније изречено, јасно је да радно способни Роми плаћају мање пореза и доприноса за социјално осигурање. Стога, очекиван је и раст економских и фискалних трошкова с обзиром на то да је ромска популација млађа и да су породице бројније од већинског становништва. Позабавимо се сада примером добре праксе чији би процеси спровођења и резултати могли да послуже као основа за побољшање.

\section{5. ПРИМЕР ДОБРЕ ПРАКСЕ}

У складу са ИПА 2012 програмом за друштвени развој, од 2013. године Организација за европску безбедност и сарадњу (ОЕБС) у партнерству са Владом Републике Србије, а из средстава Европске Уније реализовала је пројекат „Овде смо заједно - Европска подршка за инклузију Рома“. Министарство просвете, науке и технолошког развоја Републике Србије (МПНТР), уз техничку подршку Мисије ОЕПС-а у Републици Србији и Фонда за образовање Рома (РЕФ) обезбедило је стипендије за ученике ромске националности који похађају средње школе са првенственим циљем одржавања процента ромских ученика, односно смањивања одустајања истих од школовања. Пројектом је предвиђена менторска компонента,

4 Детаљни подаци, као и извештаји економске цене ексклузије Рома за Србију, Републику Чешку, Бугарску и Румунију, доступни су на сајту Светске банке www.worldbank.org/roma, односно у пдф формату на сајту siteresources.worldbank.org. 
а именовани ментори, односно изабрани наставници, те сарадници у средњим школама које похађају ученици стипендисти, обавезали су се да присуствују обукама и консултацијама, а све са циљем унапређења професионалних компетенција. Уводна обука организована је 13. и 14. јуна 2015. године у Београду. Поменути програм је заправо успешан наставак пројекта „Инклузија ромских ученика у средњим школама у АП Војводина“, који се реализовао почев од 2007-08. године (РЕФ $\left.\Phi^{5}, 2015\right)$.

Иако се пројекат „Овде смо заједно - Европска подршка за инклузију Рома“, вредан 4,8 милиона евра, који финансира Европска унија и спроводи Мисија ОЕБС-а у Србији у координацији са Канцеларијом за људска и мањинска права, састоји из шест компоненти, истакла бих две: сто седамдестет осам педагошких асистената учествује у обукама, а такође двадесет тимова за инклузију Рома обучено је и опремљено за рад на терену. ${ }^{6}$ Пројекат који обухвата двадесет пилот општина, односно градова на територији целе Србије, садржи у себи, како је већ поменуто, компоненту менторства. Дакле, кроз пројекат је подржана обука и сертификација сто седамдесет и осам педагошких асистената, као и обука за двеста ментора. Такође, пројектни тим који сачињава пет чланова, подржаће МПНТР да обезбеди образовну подршку у виду групне и индивидуалне менторске подршке ученицима који не испуњавају услове за програм стипендирања на целој територији Републике Србије.

У 2014/2015. школској години у Републици Србији у оквиру „ТАРИ“ пројекта МПНТР доделило је укупно 525 стипендија и велики број ученика испунио је услове непходне за задржавање стипендије. Штавише, готово једна петина стипендиста успела је да оствари врло добар и чак бољи успех у току школске године у којој је стипендирана у односу на претходне године школовања. Овоме треба придодати податак да је нешто мање од сто стипендиста завршних разреда, како трогодишњих тако и четворогодишњих образовних профила и смерова, успешно завршило средње школе. Имајући у виду број додељених стипендија у претходној школској години, односно број ученика који наставља да прима прима стипендију, новим конкурсом за 2014/2015. годину предвиђен је мањи број стипеднија, тачније сто се-

\footnotetext{
5 ФОР, односно РЕФ (скраћено од Roma Education Fund)je интернационална организација са седиштима у Будимпешти и Паризу, која координише Декаду Рома. Од 2005. године Србија је једна од потписница конвенције о Декади Рома, која се као међународна иницијатива залаже за бројна питања побољшања положаја Рома.

6 Преостале компоненте пројекта, резултатикао и ближе информације, који не спадају у оквир овог рада а који су свакако од значаја, доступни су на сајтуwww.facebook.com/inkluzijaroma као и на сајту Канцеларије за људска и мањинска права Владе Републике Србије.
} 
дамдесет (РЕФ, 2015). Међутим, за разлику од претходне школске године у којој је било омогућено ученицима свих разреда, завршних и незавршних, да конкуришу, ове године само ученици првог и другог разреда имају право на исто, што дакако обесхрабрује оне који прошле године нису на време били обавештени или који из других разлога нису конкурисали, док с друге стране, пружа могућност ученицима који су на почетку школовања да се залажу за задржавање стипендије. Указала бих на чињеницу да су родитељи ромске деце често додатно обесрабрени када је у питању сложена бирократска процедура, посебно у вези са припремом документације за конкурисање за стипендије, у чему би сваки ментор могао да их посаветује и укаже на који начин могу прикупити потребну документацију.

Још један од пројеката који се може подвести под тему овог рада наводи Филиповић (2009а) на примеру чешке владе која је издала концепт образовне политике која наглашава рушење језичких баријера, увођење припремних часова на ромском језику као додатном језику образовања, укључивање ромских асистената у школе, односно пружање подједнаког права на успех свим ученицима. У наставку следе резултати истраживања менторства у централној Србији.

\section{1 Истраживање менторства Ромима у области централне Србије}

Истраживање је подржало Министарство просвете, науке и технолошког развоја, а овом приликом посебно се захваљујем Раденки Васиљевић, координаторки за централну Србију на ТАРИ пројекту, која ми је несебично омогућила прослеђивање анкета менторима. Истраживање, које је обухватило тридесет ментора а који су одговарали на петнаест питања, заснива се на полуструктурираној форми интервјуа коју сам сматрала најкориснијом и најподеснијом за прикупљање валидних и поузданих података. Захваљујући детаљном извештају, описана квалитативно-квантитативна студија оставља простор читаоцима овог рада да сами просуде на које начине менторство може помоћи у унапређењу ромске, те националне и наднационалнезаједнице.

Испитаници су најпре давали опис посла ментора, које ћу покушати да сумирам у наредним редовима. Ментор пружа помоћ у учењу, прати родовност похађања наставе, сарађује са родитељима, одељенским старешином, предметним наставницима, психолошко-педагошком службом, директором школе, те локалном самоуправом. Упућујући ученика у ваннаставне активности, ментор такође помаже у успостављању добрих односа ученика са одељењем и у превазилажењу конфликтних ситуација. 
Истакнута је стална нега мотивације, упознавање са различитим методама учења, развој критичког мишљења и пружање индивидуалне помоћи уз охрабривање и похваљивање ученика за постигнуте резултате и циљеве. Такође, испитаници су наводили значај развоја самосталности код ученика, као и помоћ приликом сазревања и развоја личности. Не треба пренебрегнути чињеницу да је истакнут значај информисања ученика о правима и могућностима. Са друге стране, ментор је дужан да шаље пројектном тиму извештаје, али битакође требало да прати и процењује сопствен ангажман у циљу побољшања своје менторске улоге.

Када је реч о пружању образовне подршке путем развијања аутономије и упознавања са стратегијама учења сви ментори одговорили су да јесу дужни да је пруже. Такође, један од ментора нагласио је да се сваки ментор треба усавршавати у том погледу, док је други ментор навео и начин рада. Наиме, кроз радионице, ученици се оснажују и оспособљавају да уоче значај и разлике у техникама учења различитих садржаја. Штавише, сви испитани ментори сматрају да делују на процес формирања мотивације за континуирано учење, премда је један од ментора одговорио да су ученици углавном свесни својих могућности, те да им није потребна додатна мотивација.

Десет ментора одговорило је да не упућује ученике на екстракурикуларне програме и не подстиче развој самоиницијативних програма. С друге стране, десет је одговорило потврдно. Такође, исти број ментора одговорио је потврдно уз додатак да су ученици често несигурни, недовољно заинтересовани, те да је одзив је слаб. Један од ментора навео је да не постоји понуда оваквих програма, док је други јасно навео да реализује програм радионица са циљем јачања предузетничког духа, а који се некад завршавао на Сајму ученичког предузетништва. Из наведеног закључујемо да развоју и неговању екстракурикуларних програма треба посветити више пажње у будућности.

Једно од кључних питања односило се на начин на који програми менторства могу помоћи у сузбијању друшвене стратификације, сегрегације, предрасуда, стереотипа и угрожавања људских права. Двоје ментора изричито је истакло да раде са малим бројем ученика, а да је проблем шири. Такође, троје ментора изразило је мишљење да се оваквим проблемима мора најпре позабавити држава. Ипак, чак 50\% испитаних ментора истакло је јачање самопоштовања, самопоуздања, уверавање у иста права,истицање сопствених потенцијала код ученика, спровођење радионица о толеранцији, те мењање ставова ученика и колега. Дакле, половина испитаника јасно сматра да се у оквиру мањих заједница, тачније одељенских и школских, 
могу решавати горе-поменути проблеми. Истакла бих и да је један од ментора навео подробно бројна знања и вештине које би ментор требало да поседује, а због чега су неопходне обуке за менторе-наставнике који нису били у прилици да се као стручни сарадници стручно усавршавају. Стога, циљ јесте да се усредсредимо на резумевање али и прихвање културних разлике, које нас неће раздвајати, већ које ће нас напротив зближавати. Ево како Филиповић сумира свој став (2009а: 53).

„Уместо потраге за универзалним, униформним правилима која уређују говорно понашање уопште, усмеравамо се на анализу и тумачење разлика које не треба да нас удаље, већ да нам помогну да стварамо одразовне системе и институције које на нивоу појединца и друштвене заједнице утичу на формиразе ставова, идеологија и културних модела који уочавају и уважавају различитост, који вреднују језичке и културне особености других и које утичу на развој интеркултурне компетенције и толеранције“.

Ментори су, такође, исказали став према уврштавању садржаја који би утицали на повећање интеркултурне компетенције и прихватање различитости, да би потом дали своје идеје о могућим садржајима. Издвојила бих да се $75 \%$ испитаних ментора сложило да треба уврстити поменуте садржаје кроз различите облике радионица и вршњачку едукацију, кроз које би се ученици упознавали са другим културама, нацијама, њиховим језиком, културом, уметношћу,фолклором и обичајима. Двоје ментора напоменуло је да би могле да се организују чешће посете културним догађајима које организују различита удружења, те да би ученици могли да учествују у обележавању Светског дана језика и организују рецитаторске вечери на матерњим језицима. Један од ментора изразио је забринутост како постићи поменуто са ученицима ромске националности који нису примаоци стипендије. Преостали испитани нису навели могуће садржаје.

На питањеда ли сматрају да је потребно организовање обука за пружање подршке мултикултурном образовању, сви ментори потврдно су одговорили. Једна менторка истакла је да су обуке потребне посебно наставницима у средњим школама, навевши да је у досадашњем искуству била укључена у бројније вишегодишње пројетке у сарадњи са основним школама, а које је финансирао УНИЦЕФ, те невладине организације.

Упитани за начине на које могу утицати на формирање позитивних ставова према аутентичном наслеђу, ментори су навели најпре неговање сопственог позитивног става, те упознавање са наслеђем у оквиру предмета 
који предаје, уз сарадњу са наставницима грађанског васпитања. Издвојила бих следећи веома илустративан одговор: „Фундаментално формирање позитивних ставова према аутентичном наслеђу јесте образовање. Ментор, поред осталих карика у ланцу образовања, својим залагањем подстиче, охрабрује на поштовање националних, културних и традиционалних вредности“.

Показало се да се 60\% испитаника изјаснило позитивно, а 40\% негативно према заузимању активног става о значају плурилингвизма. Једна од менторки предложила је својој ученици усавршавање ромског на Филолошком факултету, док је друга навела да има речник ромског језика, уз помоћ којег, кроз представљање другима, тежи прихватању ромског као осталих страних језика. Овиме је доказана теза да ромски језик трпе притисак друштвено, енономски и политички јачег већинског, српског, језика.

Појам идентитета, тачније концепт друштвеног идентитета, добија на значају са порастом интересовања за етничке групе. Филиповић (2009) приступа идентитету као комплексој категорији која људе одређује у социјално-историјско-културном контексту, те која садржи синхронијску и дијахронијску компоненту, у чијом је основи процес сазнавања и идентификације. Према истраживању, повећање нивоа ентичке самосвести се може постићи кроз филм, музику, литературу (један од ментора навео је увођење одговарајућих уџбеника,часописа), упознавање са историјом, путем радионица, секција и школских манифестација, укључивањем у ученички парламент. Два ментора су предложила увођење изборног предмета на којем би се учили ромски језик, култура и обичаји. Из овога се може закључити да социолингвистика и социолингвистичка истраживања могу допринети унапређењу друштвене једнакости посебно кроз област (језичке) образовне политике и планирања. Оваква истраживања, показано je, теоријски су утемељена, друштвено ангажована и теже продуктивности.

Упитани да ли сматрају да њихови ставови могу имати значајан утицај на формирање друштвених ставова шире популације, ментори су се у већини сложили да могу, али на нивоу окружења, односно школе, те локалне заједнице. Само један ментор мисли супротно. На овај начин не само да се идентификује дискриминација, већ је јасно изражена жеља за утицајем на друштвене промене.

Сви испитаници сагласни су да менторство може утицати на повећање броја ученика који би наставили школовање, те да се тиме може утицати на превазилажење несклада у образовању и побољшање на стању тржишта рада. Двоје ментора навело је уз позитиван одговор да је потребна и подршка шире заједнице. 
Упитани на које начине би могли утицати на формирање плурикултурне и плурилингвалне Србије и Европе, занимљиво је да је један део ментора (55\%) истицао у први план важност непосредног рада, залагања, ентузијазма и љубави ментора према људима, док је други део (45\%) предложио сарадњу са другим наставницима, управом школе и локалном самоуправом, као и умрежавање ментора путем састанака, летњих школа и радионица. Издвојила бих мишљење да би „ментор требало да проследи информације и искуства у пракси која би се објединила и била укључена у законски процес образовања“.

\section{6. УМЕСТО ЗАКЉУЧКА}

Из горе наведеног, јасно је да је програм менторства ромске деце у средњим школама у својој почетној фази. Конструктивна комуникација са учеником, родитељима, колегама, као и представницима локалне заједнице неопходан је чинилац описа посла ментора. У процесу менторства ученик преузима већу одговорност за сопствени развој, подиже свест о себи и сопственим вештинама, знањима и компетенцијама, док ментор са друге стране препознаје вишеструке користи од професионалног развоја и учења. Да би рад ментора уродио плодом потребно је остварити и ширу сарадњу са школом и школском управом, локалном заједницом, Министарством просвете, као и са представницима ромских невладиних организација. Мењајући традиционалну учионицу, ментори би требало да гаје и преносе критички став према свакој врсти дискриминације, те тиме смањују културни, образовни, политички и економски притисак који трпи и даље маргинализована и стигматизована мањинска ромска заједница.

Залажем се за виђење да би ментори могли да утичу на своје ученике у формирањупозитивних ставова према аутентичном наслеђу, специфичностима ромског језика и културе уопште, као и на подизање нивоа етничке самосвести и престижа ромске мањине, што би даље могло доприносити унапређењу ромске заједнице а тиме и шире друштвене, односно државне заједнице. Ментори морају бити свесни своје улоге, те идеје да њихови ставови могу имати значајан утицај на формирање друштвених ставова, свести и мишљења шире популације.Премда не можемо рећи да не постоји национална и наднационална институционална подршка, од велике је важности предузети мање коракекоји би последично доводили до бољег економског статуса Рома и њиховог приступа образовању, те институцијама друшвене моћи. 
Када је реч о образовној језичкој политици, будућност наставе у Србији требало би дапрати савремене научне токове и да задовољава потребе појединца, односно потребе ромске националне мањине. Сложила бих се са Филиповић (2009а) да однос идеолошких, епистемолошких и друштвено-политичких фактора утиче на ЈПП, односно на ОЈПП. Такође, наглашено је да сваки будући (билингвални) курикулум мора узети у обзир идеју интеркултурне комуникативне компетенције, где би сваки појединац вредновао сопствено наслеђе, плурализам и универзалне људске вредности (Филиповић, Вучо и Ђурић, 2007; Филиповић 2009а; заграде је додала ауторка овог рада). Речју, однос према ромском језику и уопштено према језичким људским правима уз залагања планера и свих који спроводе језичку политику, а ту подразумевам и менторе, може имати светлу будућност у Србији. Тиме би се садашњим али и будућим генерацијама обезбедио професионални и лични развој у друштвеном миљеу у којем би се развијала толеранција, неговала интеркултурна кометенција и подржавало подједнако учешће свих чланова друшта у формирању плурикултурне и плурингвалне Србије и Европе.

Иако је потребна институционална подршка како би мањинске заједнице оствариле основна људска, односно језичка људска права, која би им гарантовала очување животног и културног интегритета и етнојезичког идентитета, ментори могу неговати мишљење да препознавање сопственог језика као ресурса мора претходити институционалној подршци. Премда концепт језичких људских права у смислу права ромског језика да се користи као Л1 у свим доменима звучи утопистички, такво виђење не оправдава занемаривање потребе да се ромски језик уважава и да се на нивоу државе донесу у пракси применљиви закони који би гарантовали и подржавали његову ширу употребу.

Сложила бих се са Филиповић (2009а) да образовне институције, како националне, тако и наднационалне, треба да пруже финансијска средства, стратегију и компетенције за развој вижекултурних и вишејезичких курикулума, како би нови културни модели били схваћени као предности. Објективно посматрано, Ромима треба обезбедити приступ већинском језику образовања, односно српском у Србији, уз активно неговање лингвокултурних различитости ромске етничке, односно етнојезичке, заједнице.

Једнако учешће Рома на тржишту рада битно би утицало на смањење трошкова који расту на националном, те наднационалном нивоу, а који се односе, на пример, на расходе на пензије и здравство. Економске и фискалне губитке треба претварати у добитке а један од првих корака је пружање подршке Ромима у току школовања и усмеравање ка високом образовању. 
Не треба заборавити да потенцијални добици од инклузије Ромазнатно превазилазе неопходне трошкове улагања. Демографски млађа ромска популација би требало стога да преузима све већи удео у радно спосодном а запосленом становништву. Доказано је да су трошкови улагања у инклузивно и квалитетно образовање ромске деце мањи од добити које они могу доносити влади.

У будуће морамо се детаљно позабавити редефинисањем, постмодернистички речено, деконструкцијом појмова попут расе, етницитета, идентитета, језика, као и политике језика и планирања. У раду сам тежила да укажем на болна места у друштвеним односима наше свакодневице, на неопходност превазилажења или бар ублажавања друштвених и културних разлика и доминације, на, надам се, светлу будућност стварања нових друштвених и културних норми које ће имати за циљ редефинисање концепта личног и групног идентитета.

Поменути пројекат „Овде смо заједно - Европска подршка за инклузију Рома“"пружа подршку МПНТР у спровођењу и успостављању програма који уз запажену менторску компонентуима за циљ спречавање напуштања школовања ромске деце у средњим школама. Наглашавам да би прогресивно и упорно спровођење политике на микроплану, што би у нашем случају биле средње школе, даље водило интра и интеретничком дијалогу, развоју јединственог тржишта рада, као и брисању граница. Залажем се за такав контекст у коме би се неговало вишекултурно и вишејезичко образовање, развијала толеранција, уочавале предности различитости идентитета, подстицала интеграција насупрот асимилацији и подизао ниво критичке свести о значају разноврсности у језичком, културном и социјалном миљеу.

\section{ЛИТЕРАТУРА НА СТРАНОМ ЈЕЗИКУ}

Filipović J., J. Vučo \& Lj. Đurić.(2007). "Critical review of language education policies in compulsory primary and secondary education in Serbia". Current issues in Language Planning: Vol. 8:1: 222-242.

Filipović, J. \& J. Vučo. (2012). "Language policy and planning in Serbia: language management and language leadership". AnaliFilološkogfakulteta24 (II): 9-32.

O’Nions, H.(2010). "Different and unequal: the educational segregation of Roma pupils in Europe". InterculturalEducation, 21 (1):1-13.

Parsloe, E. (1992). Coaching, Mentoring and Assessing: a Practical Guide to Developing Competence. London: Kogan Page. 
Rolfe, A. (2006). How To Design and Run Your Own Mentoring Program. Terrigal N.S.W: Mentoring Works.

Roma Education Fund - REF. (2007).“Advancing Education of Roma in Serbia”. Будимепешта: REF.

OSCE.(2006). "Monitoring Education for Roma 2006: a Statistical Baseline for Central, Eastern and SouthEastern Europe Open Society Institute Education Support Programme". Pristupljeno28.6. 2015. URL: <https://www.opensocietyfoundations.org/sites/default/files/ monitoring_20061218.pdf $>$.

The World Bank.(2014). "Promoting Roma Inclusion in Eastern Europe". Pristupljeno20.6. 2015. URL: $<$ http://www.worldbank.org/en/ results/2014/04/10/promoting-roma-inclusion-in-eastern-europe $>$.

Литература на српском језику

Бугарски, Р. (2005). Језик и култура. Београд: XX век. [Бугарски, Р. (2005). Језик и култура. Београд: ХХ век.]

De Laat, J. (2010).“Ekonomska cena ekskluzije Roma”. The World Bank. Pristupljeno 5. 7.2015. URL: <http://siteresources.worldbank.org/ EXTROMA/Resources/SERB_Economic_Costs_Roma_Exclusion_Note_ Final3.pdf $>$.

Жиропађа, Љ. (2012).Увод у психологију. Београд: Чигоја. [Žiropađa, LJ. (2012).Uvod u psihologiju. Beograd: Čigoja.]

Mikes, М. (2001).“Кад су границе само тарабе. Истраживања двојезичности у Војводини”. Нови Сад: Југословенско друштво за примењену лингвистику и Футура. [Mikes, M. (2001).“Kad su granice samo tarabe. Istraživanja dvojezičnosti u Vojvodini”. Novi Sad: Jugoslovensko društvo za primenjenu lingvistiku i Futura.]

Канцеларија за људска и мањинска права Владе Републике Србије. (2015). “Овде смо заједно”.Београд: Канцеларија за људска и мањинска права Владе Републике Србије. Приступљено 10. 8. 2015. [Kancelarija za ljudska i manjinska prava Vlade Republike Srbije. (2015). "Ovde smo zajedno". Beograd: Kancelarija za ljudska i manjinska prava Vlade Republike Srbije. Pristupljeno 10. 8. 2015.] URL: <http://www. ljudskaprava.gov.rs/index.php/yu/projekti-1/97-ovde-smo-zajedno/949ovde-smo-zajedno0>.

Канцеларија Савета Европе у Београду. Пиступљено 15. 8. 2015. [Kancelarija Saveta Evrope u Beogradu. Pistupljeno 15. 8. 2015.] URL: <http://www. coe.org.rs/def/tdoc_sr/council_of_europe/coe_institutions/?conid=18>. 
Програм Уједињених нација за развој (United Nation's Development Program -UNDP). (2006). "U opasnosti: Romi i raseljena lica u Jugoistocnoj Evropi”. Братислава: UNDP. Приступљено 1. 7. 2015. [Program Ujedinjenih nacija za razvoj (United Nation's Development Program -UNDP). (2006). "U opasnosti: Romi i raseljena lica u Jugoistocnoj Evropi”. Bratislava: UNDP. Pristupljeno 1. 7. 2015.] URL: <http://www. romadecade.org/cms/upload/file/8473_file2_summary-serbian.pdf $>$.

Републички завод за статистику и UNICEF.(2014). "Истраживање вишеструких показатеља положаја жена и деце у Србији 2014. и Истраживање вишеструких показатеља положаја жена и деце у ромским насељима 2014, Коначни резултати".Београд, Србија: Републички завод за статистику и UNICEF. Приступљено 28. 7. 2015. [Republički zavod za statistiku i UNICEF.(2014). "Istraživanje višestrukih pokazatelja položaja žena i dece u Srbiji 2014. i Istraživanje višestrukih pokazatelja položaja žena i dece u romskim naseljima 2014, Konačni rezultati”.Beograd, Srbija: Republički zavod za statistiku i UNICEF. Pristupljeno 28. 7. 2015.] URL: $<$ http://mics.unicef.org/>.

Филиповић, J. (2009a). Моћ речи: огледи из критичке социолингвистике. Београд: Задужбина Андрејевић. [Filipović, J. (2009a). Moć reči: ogledi iz kritičke sociolingvistike. Beograd: Zadužbina Andrejević.]

Филиповић, J. (2009б). “Српски као језик образовања за ромску децу из реадмисије и интерно расељену ромску децу: модел језичке подршке", у Индивидуализаиија у настави језика, ед. Ј. Вучо (Никшић: Филозофски факултет Универзитета Црне Горе). Приступљено: 15. 2. 2016. [Filipović, J. (2009b). "Srpski kao jezik obrazovanja za romsku decu iz readmisije i interno raseljenu romsku decu: model jezičke podrške", u Individualizacija u nastavi jezika, ed. J. Vučo (Nikšić: Filozofski fakultet Univerziteta Crne Gore). Pristupljeno: 15. 2. 2016.] URL: <https://www. academia.edu/4024898/Model_jezicke_podrske_za_romsku_decu_u_ readmisiji $>$. 


\author{
Olivera Petrović \\ University of Belgrade \\ Faculty of Philology - doctoral studies, module Culture \\ Belgrade \\ Electrotechnical School in Smederevo \\ Smederevo \\ olivera.petrovic1988@gmail.com
}

\title{
THE ROLE OF A MENTOR TO ROMA SECONDARY-SCHOOL STUDENTS
}

\section{Summary}

Herein, the role of a mentor to Roma secondary-school students is outlined from a sociolinguistics perspective, i.e. interculturalism. The description of what a mentor should do has been accompanied by the notions of language education policy and planning theory, along with the attitudes towards the Roma language and its interactions with Serbian. Concepts of mentorship are introduced and applied to education language policy and planning, with reference to the concepts of intercultural competence and multilingualism. Furthermore, a successful mentorship programme is provided through an illustration of the effectiveness of the TARI project in Serbia. Ensuring a complete and successful integration of Roma students, the mentors from central Serbia have testified that the afore-mentioned programme provides long-term benefits. The paper offers evidence and argumentation for a fresh approach to education policy and planning, while the present analysis identifies theoretically sound and practically applicable solutions. Hardly can we neglect the importance of a mentor in fostering positive attitudes towards Roma authentic cultural heritage and language as well as in nurturing motivation for lifelong learning. An argument is made that every mentor enhances ethnic self-consciousness and the prestige of Roma minority, which in turn contributes to a better well-being of Roma community and consequently to national and international community.

Key words: Roma students, mentor, mentorship, language education policy and planning, plurilingualism, intercultural competence, the TARI project, the price of exclusion

Примљено: 31. 3. 2016. Прихваћено: 9. 5. 2016. 